\title{
SYTUACJA EDUKACYJNA MAEOLETNICH MATEK, WYCHOWANEK PLACÓWEK OPIEKUŃCZO-WYCHOWAWCZYCH. PERSPEKTYWA BIOGRAFICZNA
}

\begin{abstract}
Skowrońska-Pućka Agnieszka, Sytuacja edukacyjna małoletnich matek, wychowanek placówek opiekuńczo-wychowawczych. Perspektywa biograficzna [Educational Situation of Minors Mothers, Pupil Childcare Centers. Biographical Perspective]. Studia Edukacyjne nr 40, 2016, Poznań 2016, pp. 191211. Adam Mickiewicz University Press. ISSN 1233-6688. DOI: 10.14746/se.2016.40.12
\end{abstract}

One of the most severe consequences resulting from premature motherhood is the inability or shortening of the education period. Author's empirical verification indicate that the majority of researched girls (underage mothers, educational care facilities foster-children) quickly leave school and interrupt education once their child is born. The narration analysis indicated that its main cause was the difficulty in combining the role of a mother and a student, together with the lack of support from the closest. Only few girls managed to continue education, unfortunately they chose private, evening schools which are known for low quality education. The presented fragmentary empirical verifications indicate that early parenthood reduces the education period. Educational-care facilities foster-children, coming from low-educated families and professional qualifications find it particularly hard or impossible to achieve secondary or even lower-secondary education. Lack of education and professional qualifications has lead them to take up low-income jobs, that do not require any qualifications or to obtain money illegally.

Recognizing various consequences of premature motherhood, both individual and social, there is no doubt that teenage mothers, especially foster children of educational-care facilities, should be taken care of.

There is only one legal record concerning the education of pregnant student or underage mothers, however, it is not precise, which means that schools have to interpret it by themselves and introduce their own procedures. The subject of the present article is prevention, support and help given to underage pregnant students or underage mothers by the teachers, educators, or peers, who are potential beneficiaries of help, i.e. underage mothers fulfilling the education duty.

Key words: premature maternity, underage mothers, educational care facilities foster-children, education 


\section{(Przed)wczesne? macierzyństwo}

Wczesne macierzyństwo, czy szerzej rodzicielstwo, należy do zjawisk często spotykanych w Indiach, Afganistanie, Jemenie, państwach islamskich, czy Arabii Saudyjskiej ${ }^{1}$. W krajach europejskich, w kulturze europejskiej ciążę niepełnoletniej dziewczyny należy zaliczyć do zjawisk powszechnie nieakceptowanych, a często nawet potępianych. Rewolucja przemysłowa, rozwój szkolnictwa oraz zmiana nastawienia społecznego do praw dziecka, a także oczekiwań względem życia i jego jakości wydłużyły okres dorastania, wpływając korzystnie na warunki rozwoju, czy szerzej - życia adolescentów ${ }^{2}$. Należy wskazać, iż również powszechnie obowiązująca akceptacja modelu życia, w którym najpierw zdobywa się (coraz wyższe) wykształcenie, $\mathrm{w}$ dalszej kolejności niezależność finansową oraz mieszkaniową, sprawiają, że ciąże nastolatek określa się wielokrotnie mianem (przed)wczesnych ${ }^{3}$.

Ciążę niepełnoletniej dziewczyny można uznać za (przed)wczesną z co najmniej kilku powodów. Przede wszystkim należy podkreślić ciężar wielowymiarowych konsekwencji z nią związanych. Mam tu na myśli implikacje o charakterze emocjonalnym, edukacyjnym, zawodowym, czy szerzej - społecznym, nierozerwalnie związane $\mathrm{z}$ zaistnieniem tego niepunktualnego $\mathrm{w}$ biografii młodej kobiety wydarzenia. W sposób szczególny termin ten charakteryzuje macierzyństwo nastoletnich dziewcząt będących wychowankami placówek opiekuńczo-wychowawczych ${ }^{4}$. W takiej sytuacji (przed)wczesna ciąża dodatkowo umacnia i tak już gorsze położenie społeczno-ekonomiczne dziewcząt $\mathrm{z}$ defaworyzowanych grup. Ponadto, $\mathrm{w}$ zaistniałych okolicznościach grupa ta może przejawiać poważne problemy z właściwą realizacją zadań wynikających z macierzyństwa, co warunkowane jest nierzadko brakiem odpowiednich wzorców $\mathrm{w}$ ich rodzinach pochodzenia ${ }^{5}$. Termin (przed)wczesne macierzyństwo jest $\mathrm{w}$ tym przypadku również uzasadniony, ponieważ już Erik Erikson czy Robert Havighurst wskazali, iż zadania

${ }^{1}$ M. Bidzan, Nastoletnie rodzicielstwo. Perspektywa psychologiczna, Gdańsk 2013, s. 10.

2 Tamże.

3 Por. Z. Izdebski, T. Niemiec, K. Wąż, (Zbyt)młodzi rodzice, Warszawa 2011; A. Skowrońska-Zbierzchowska, Doświadczenia małoletnich rodziców, Gdańsk 2010.

${ }^{4}$ Jedną z form pomocy małoletniej dziewczynie będącej w ciąży lub małoletniej matce jest umieszczenie jej w placówce opiekuńczo-wychowawczej. Dzieje się tak w sytuacji, kiedy małoletnia nie może liczyć na pomoc rodziny pochodzenia, a ciąża może lub przyczynia się do pogłębienia dysfunkcji w niej występujących.

${ }^{5}$ Por. P. Bunio-Mroczek, W. Warzywoda-Kruszyńska, Wczesne rodzicielstwo jako zagrożenie bieda $i$ wykluczeniem spotecznym, 2010, http://www.wzlot.uni.lodz.pl/pub/dokumenty/ 123234.pdf, [dostęp: 7.05.2016]. 
związane z rodzicielstwem powinny być realizowane przez osoby dorosłe, a więc na późniejszych etapach życia. Zdaniem wspomnianych autorów, wybór małżonka, założenie rodziny, prowadzenie domu to zadania rozwojowe wczesnej dorosłości. Zatem, osoby znajdujące się w okresie adolescencji nie są do ich realizacji przygotowane ${ }^{6}$. W tak niesprzyjających okolicznościach również realizacja zadań rozwojowych okresu dorastania, zdaniem wielu autorów, jest utrudniona ${ }^{7}$. Obowiązki rodzicielskie utrudniają realizowanie kolejnych powinności adolescenta, a zmaganie się $\mathrm{w}$ tym czasie z zadaniami rozwojowymi okresu dorosłości powoduje współwystępowanie kryzysu normatywnego i nienormatywnego ${ }^{8} \mathrm{w}$ tym samym czasie. W sytuacji rodziców dorosłych narodziny potomka można interpretować przez pryzmat kryzysu rozwojowego, normatywnego. To wydarzenie $w$ ich życiu należy uznać za naturalny, kolejny etap, co zwiększa szansę na jego pozytywne rozwiązanie. Warto jednak zaznaczyć, że narodziny dziecka w wieku nastoletnim mogą przyczynić się do wystąpienia kryzysu sytuacyjnego nieoczekiwanego, nierozwojowego ${ }^{9}$. Taka sytuacja ma miejsce jeśli wydarzenie to wystąpi $\mathrm{w}$ nieodpowiednim czasie i towarzyszyć mu będą niesprzyjające okoliczności. Tak zdarzenie krytyczne definiuje Anna Brzezińska, określając je mianem wydarzeń życiowych, i dzieli na punktualne i niepunktualne. Używając terminologii wspomnianej autorki, ciąża dziewczyny małoletniej należy do zdarzeń krytycznych, niepunktualnych. Są to bowiem wydarzenia, które występują zbyt wcześnie z punktu widzenia biologicznego rozwoju. Ciąża i narodziny dziecka w wieku nastoletnim niewątpliwie należą do zdarzeń, które mogą zaburzać funkcjonowanie i prowadzić do załamania linii prawidłowego rozwoju człowieka ${ }^{10}$. Warto w tym miejscu zasygnalizować fakt, iż nastoletnie matki, wychowanki placówek opiekuńczo-wychowawczych, mają za sobą pewną historię, zazwyczaj problemy relacyjne $\mathrm{w}$ ich rodzinach pochodzenia, nieodpowiednie wzorce zachowań, których były świadkami w domu rodzinnym. Wszystko to będzie modyfikowało i utrudniało odnalezienie się w tej trudnej, niejednokrotnie krytycznej, dla nich sytuacji1 ${ }^{11}$.

6 A. Brzezińska, Wydarzenia punktualne i niepunktualne w okresie dzieciństwa $i$ dorastania, Remedium, 2003, 12(130), s. 47-48; M. Bidzan, Nastoletnie rodzicielstwo, s. 9.

${ }^{7}$ M. Bidzan, Nastoletnie rodzicielstwo, s. 36.

8 A. Brzezińska, Wydarzenia punktualne i niepunktualne, s. 47-48; tamże, s. 9.

${ }^{9}$ M. Bidzan, Nastoletnie rodzicielstwo, s. 12.

10 Por. A. Brzezińska, Społeczna psychologia rozwoju, t. 3, Warszawa 2000; tejże, Wydarzenia punktualne i niepunktualne.

11 Por. A. Skowrońska-Pućka, (Przed)wczesne macierzyństwo - perspektywa biograficzna. Diagnoza, pomoc $i$ wsparcie, niepublikowana rozprawa doktorska. 


\section{Skala zjawiska w Polsce}

W Polsce ciąże nastolatek stanowią 3,4-8\% wszystkich ciąż ${ }^{12}$.

Za młodociane matki uważa się kobiety, które zaszły w ciążę i (lub) urodziły do 18. roku życia. Wyodrębnia się tu kilka podgrup:

- bardzo młoda matka - do 16 lat;

- starsza nastolatka - od 16 lat;

- nastolatka samotna, nie mająca oparcia ze strony rodziny lub partnera;

- nastolatka mająca wsparcie i pomoc ze strony partnera i (lub) rodziny ${ }^{13}$.

Dane Głównego Urzędu Statystycznego z 2013 roku wskazują na prawie 14500 żywych urodzeń przez nastolatki (poniżej 19. roku życia). Najczęściej rodziły 19-latki (6771); dla 5939 z nich było to pierwsze dziecko, dla 779 drugie, a dla 48 z nich - trzecie, a cztery 19-latki miały już czwórkę dzieci. 18-latki wydały na świat 4278 dzieci; dla 3938 było to pierwsze dziecko, dla 312 - drugie, dla 16 z nich - trzecie. Dziewczęta 17-letnie wydały na świat 2271 dzieci; dla 91 z nich było to już drugie dziecko, a dla dwóch 17-latek już trzecie. 886 dzieci stanowiło potomstwo 16-latek: $18 \mathrm{z}$ nich rodziło już po raz drugi, jedna 16-latka była matką trójki dzieci. Dziewczęta poniżej 15. roku życia wydały na świat 286 dzieci: dla jednej z nich było to już drugie dziecko14. Mimo zmniejszania się liczby potencjalnych młodych matek, należy zauważyć, że systematycznie spada w naszym kraju liczba dzieci do 18. roku życia - z 8446 tys. w 2005 roku do 7432 tys. w roku 2013 - każdego roku skala zjawiska utrzymuje się na podobnym poziomie, a co znamienne wzrasta liczba ciąż wśród nastolatek 15-16-letnich ${ }^{15}$.

\section{Założenia metodologiczne własnych weryfikacji empirycznych}

Przyczynkiem do zainteresowania się problematyką macierzyństwa nastolatek stały się moje doświadczenia zawodowe związane z pracą w pla-

12 M. Bidzan, Nastoletnie rodzicielstwo, s. 22.

13 Por. P. Szukalski, Nastoletnie macierzyństwo we wspótczesnej Polsce, Polityka Społeczna, 2011, 1, s. 16-17; U. Kempińska, Małżeństwa młodocianych. Ciąża, ślub i co dalej...? Torun 2012, s. 70; B. Frankowicz-Gasiul i in., Ciaża młodocianych - problem medyczny i społeczny, Studia Medyczne, 2008, s. 58, http://docplayer.pl/6714134-Ciaza-mlodocianych-problem-medycznyi-spoleczny.html [dostęp: 2.02.2014].

14 Rocznik Demograficzny 2013, http://stat.gov.pl/obszary-tematyczne/roczniki-statysty czne/roczniki-statystyczne/rocznik-demograficzny-2014,3,8.html, [online] dostęp: 11.01.2015.

${ }_{15}$ P. Szukalski, Nastoletnie macierzyństwo we wspótczesnej Polsce, s. 15. 
cówce opiekuńczo-wychowawczej, specjalizującej się w opiece nad małoletnimi matkami. Macierzyństwo wychowanek placówek opiekuńczo-wychowawczych można uznać za „macierzyństwo trudne”, ponieważ realizowane przez dziewczęta, które wielokrotnie nie miały możliwości nawet obserwowania (nie mówiąc o uczestnictwie) pozytywnych wzorców macierzyńskich (czy szerzej rodzicielskich), ponieważ pochodziły ze środowisk zmarginalizowanych i dysfunkcyjnych, dotkniętych alkoholizmem, przemocą, skrajnym ubóstwem, chorobą psychiczną. Wywodziły się z rodzin, w których nieodpowiedni wzorzec płodności przekazywany był z pokolenia na pokolenie, ponieważ zarówno babki, matki, jak i siostry wcześnie rodziły dzieci.

Będąc $\mathrm{w}$ bezpośrednim kontakcie $\mathrm{z}$ dziewczętami, które doświadczyły (przed)wczesnego macierzyństwa ${ }^{16}$, a także w związku ze specyfiką i charakterem przedmiotu badań oraz podjętych problemów badawczych, tu jedynie zasygnalizowanych, oscylujących wokół odbywającego się w warunkach instytucjonalnych "trudnego macierzyństwa", które wielokrotnie wyraża się negatywnymi przeżyciami i stanami emocjonalnymi matki, jej dylematami moralnymi oraz zaburzeniem tworzenia macierzyńskiej roli ${ }^{17}$, a także ze względów metodologicznych oraz humanistycznych, dla celów realizacji badania wybrałam jakościowy sposób prowadzenia weryfikacji empirycznych, który pozwala

ukazać niemierzalne, subiektywne zjawiska, poznać doświadczenia konkretnych osób w ich środowisku życia, rozpoznać znaczenia im przypisywane, a więc wejść „W głąb" problemu badawczego'18.

Podejście jakościowe (zastosowano metodę biograficzną, wywiad pogłębiony) pozwoliło na podjęcie zagadnienia dotyczącego zjawisk złożonych treściowo i znaczeniowo w odniesieniu do jednostkowych przypadków.

Przyjęcie postawy „naiwnej poznawczo", co równoznaczne jest z zawieszeniem na czas badań osobistych przekonań, nastawień, oczekiwań, sądów pozwoliło na realizację postulatu „bezzałożeniowości” badań jakościowych $^{19}$.

\footnotetext{
16 Bezpośredni kontakt wynikał z pracy zawodowej badacza w Domu Matki i Dziecka Caritas Archidiecezji Gnieźnieńskiej w Gnieźnie.

17 Por. A. Maciarz, Macierzyństwo w kontekście zmian spotecznych, Warszawa 2004, s. 24.

18 Por. D. Kubinowski, M. Nowak, Metodologia pedagogiki zorientowanej humanistycznie, Kraków 2006; D. Kubinowski, Jakościowe badania pedagogiczne. Filozofia, metodyka, ewaluacja, Lublin 2010; T. Pilch, T. Bauman, Zasady badań pedagogicznych. Strategie ilościowe i jakościowe, Warszawa 2001, J. Włodarek, M. Ziółkowski, Metoda biograficzna w socjologii, Warszawa - Poznań 1990; A. Skowrońska-Zbierzchowska, Doświadczenia małoletnich rodziców, s. 77.

${ }^{19}$ Por. T. Pilch, T. Bauman, Zasady badań pedagogicznych, s. 279.
} 
W badaniu uczestniczyły matki, które spełniały następujące szczegółowe warunki:

- zaszły w ciążę lub urodziły dziecko przed osiągnięciem pełnoletności, dodatkowo przed, $\mathrm{w}$ trakcie ciąży lub z dzieckiem trafiły do placówki opiekuńczo-wychowawczej na skutek ograniczenia lub pozbawienia władzy rodzicielskiej ich własnych rodziców lub opiekunów;

- wyraziły zgodę na przeprowadzenie badań i wykorzystanie uzyskanych od nich informacji do celów naukowych;

- przebywały z dzieckiem w placówkach opiekuńczo-wychowawczych (lub innych instytucjach) na skutek ograniczenia lub pozbawienia władzy rodzicielskiej ich własnych rodziców dłużej niż 2 lata;

$-\mathrm{w}$ momencie prowadzenia badania upłynęły co najmniej 2 lata od opuszczenia przez nie placówki.

Do rozmówców docierałam drogą formalną, jak też poprzez kontakty nieformalne (kiedy to dziewczęta wskazywały mi kolejne osoby, w których doświadczenie wpisała się zarówno (przed)wczesna ciąża, jak i pobyt w placówce opiekuńczo-wychowawczej). Terenem badań uczyniłam naturalne środowisko badanych matek - miejsca i okoliczności, które same wskazały. Najczęściej były to mieszkania rodziców badanych kobiet, ich własne mieszkania lub teren instytucji udzielających im wsparcia.

$\mathrm{W}$ badaniach skoncentrowałam się na następujących segmentach zagadnień:

1. Kryzys podwójnego uwikłania biograficznego spowodowanego (przed)wczesną ciążą i jednoczesnym umieszczeniem w placówce opiekuńczo-wychowawczej.

2. Funkcjonowanie $\mathrm{w}$ nowej roli - pełnienie obowiązków macierzyńskich, godzenie roli matki z rolą uczennicy i innymi charakterystycznymi dla adolescenta rolami społecznymi, reakcje najbliższego otoczenia.

3. Ocena małoletnich matek dotycząca roli placówki opiekuńczowychowawczej oraz innych instytucjonalnych i pozainstytucjonalnych form wsparcia adresowanych dla małoletnich matek, w tym także ich postulaty i oczekiwania w zakresie wsparcia społecznego.

W każdym z tych obszarów ukazałam pola problemowe, które zostały rozpoznane $\mathrm{w}$ toku weryfikacji empirycznych. Oto przykłady, istotne $\mathrm{z}$ uwagi na podjętą $\mathrm{w}$ niniejszym artykule problematykę:

- Obraz dzieciństwa i wczesnej młodości w relacjach kobiet, które urodziły dziecko przed osiągnięciem pełnoletności - doświadczenia szkolne dziewcząt, charakterystyka grupy rówieśniczej badanych kobiet.

- Reakcje na wieść o ciąży - reakcja środowiska szkolnego na wieść o ciąży, plany (m.in. edukacyjne), obawy, oczekiwania badanych kobiet związane z zaistniałą sytuacją. 
- Doświadczenia związane $\mathrm{z}$ umieszczeniem małoletnich dziewcząt w placówce opiekuńczo-wychowawczej - doświadczenia związane z funkcjonowaniem $\mathrm{w}$ POW $\mathrm{w}$ trakcie ciąży (przed urodzeniem) - nowe otoczenie - reguły i zasady panujące $\mathrm{w}$ POW, nowa grupa rówieśnicza, sytuacja szkolna.

- Funkcjonowanie w szkole po urodzeniu dziecka - szeroko rozumiana sytuacja szkolna, poziom i formy wsparcia ze strony środowiska szkolnego, godzenie roli matki z rolą uczennicy, opis dnia, obowiązków, problemów, porównanie przeszłości z teraźniejszością.

- Konsekwencje wynikające z zaistnienia (przed)wczesnego obowiązku macierzyńskiego - w zakresie życia szkolnego i dalszej edukacji.

Na potrzeby niniejszego artykułu szeroko rozumiana sytuacja edukacyjna małoletnich uczennic w ciąży lub uczennic z dzieckiem, będących wychowankami POW, ukazana zostanie $\mathrm{w}$ trzech perspektywach temporalnych. Najpierw opisane zostaną doświadczenia szkolne dziewcząt przed zaistnieniem ciąży i przed umieszczeniem ich w placówce. Następnie scharakteryzowana zostanie sytuacja edukacyjna $\mathrm{w}$ trakcie pobytu dziewcząt w POW, przy jednoczesnym realizowaniu zadań matki i uczennicy. Następnie skupię się na opisaniu edukacyjnych konsekwencji wynikających z (przed)wczesnego macierzyństwa odczuwanych przez badane kobiety po opuszczeniu placówki.

\section{Doświadczenia szkolne w narracjach małoletnich matek, wychowanek placówek opiekuńczo-wychowawczych przed umieszczeniem w placówce opiekuńczo-wychowawczej i zaistnieniem ciąży}

Narracje dziewcząt biorących udział w badaniu wskazują, że w domach małoletnich matek, wychowanek placówek opiekuńczo-wychowawczych sfera związana z edukacją nigdy nie należała do priorytetowych. Pomimo to, większość $\mathrm{z}$ nich nie miała większych problemów $\mathrm{w}$ nauce $\mathrm{w}$ szkole podstawowej.

[Julia] W podstawówce było dosyć dobrze nie? Tam normalnie się uczyłam. To w gimnazjum tak się zaczęło, bo koleżanki i tak dalej. (...). W podstawówce przechodzitam z klasy do klasy bez problemu. Zaczęło się w gimnazjum. Wtedy nie przeszłam właśnie w pierwszej raz i potem drugi. To przez nieobecności.

$\mathrm{Na}$ problemy $w$ szkole gimnazjalnej wskazują już wszystkie badane dziewczęta. $\mathrm{Z}$ narracji biorących udział $\mathrm{w}$ badaniu dziewcząt wyłania się 
kilka zasadniczych problemów. Większość dziewcząt, która brała udział $\mathrm{w}$ prezentowanych tu, jedynie fragmentarycznie, weryfikacjach empirycznych, w szkole gimnazjalnej zaczęła opuszczać zajęcia lekcyjne.

[Ola] My do szkoły rzadko chodziliśmy, bo chodziliśmy na blauki. (...) jechaliśmy sobie na blaukę. (...) albo w domu se spatam. Jak mama szła później do roboty... To nie musiałam wstać, no bo szła na 6:00, ja miałam na 8:00 do szkoły. To mogłam sobie spać. Mówitam, że do szkoty idę, a nie szłam do szkoty. (...).

Dziewczęta przyczyn problemów szkolnych, a dokładniej trudności $\mathrm{w}$ realizacji obowiązku szkolnego, upatrywały najczęściej w trudnej sytuacji rodzinnej (choroba alkoholowa rodziców, przemoc, brak konsekwentnych oddziaływań wychowawczych i motywacyjnych). Wskazywały również na "nieodpowiednie towarzystwo" oraz brak wsparcia i zainteresowania ze strony nauczycieli. Bardzo często podkreślały, że bezpośrednią przyczyną niezrealizowania obowiązku nauki była konieczność realizacji zadań, które powinny być udziałem ich rodziców, myślę tu o opiece nad (często) licznym rodzeństwem.

[Renata] (...) ja wyprawiałam młodych do szkoty, siebie do szkoły. Wracałam wcześniej ze szkoty, żeby ich odebrać ze szkoty. Później te wszystkie moje kible, jak to się mówi, miałam za to właśnie nieklasyfikację, bo nie miałam kiedy chodzić do szkoty. (...).

Wypowiedzi dziewcząt wskazują, że dla wielu rodzin małoletnich matek charakterystyczny jest całkowity brak realizacji podstawowych powinności rodzicielskich oraz sytuacje, w których dzieci przejmują zadania rodziców. Katarzyna Schier określa to zjawisko parentyfikacjąa ${ }^{20}$ Warto wskazać, że opisywana sytuacja była bardziej charakterystyczna dla dziewcząt wychowujących się w rodzinach wielodzietnych.

Ola, jedna $\mathrm{z}$ dziewcząt biorących udział $\mathrm{w}$ badaniu, która miała aż ośmioro rodzeństwa, wskazuje w swojej wypowiedzi, że opiekowała się rodzeństwem z uwagi na pracę zarobkową rodziców. Wskazuje również, iż stopień poświęcanej potomstwu uwagi uzależniony był od ich wieku, tzn. im starsze dzieci, tym mniej uwagi im poświęcano.

[Ola] (...) No to tam dtużej uwagi nie mieliśmy poświęcanej, to nie powiem, bo dużej nie mieliśmy poświęcanej. Bo dużo osób w rodzinie, to tam się nie dziwie. (...) Tym najmłodszym było więcej, ale my jak już coraz starsi to coraz tak mniej (...).

Nierealizowanie obowiązku nauki stało się jednym z podstawowych powodów umieszczenia małoletnich dziewcząt w placówce opiekuńczowychowawczej. Jak wskazywały na to w swoich narracjach, do placówek

20 A. Pasternak, K. Schier, Życie bez dzieciństwa - parentyfikacja u kobiet z syndromem DDA, Psychiatria Polska, 2014, 48(3), s. 553-562. 
opiekuńczo-wychowawczych trafiały zazwyczaj po doświadczeniu długotrwałego procesu pogłębiającej i wzmagającej się niewydolności ich rodzin pochodzenia, która dotykała wiele sfer codziennego funkcjonowania.

[Julita] Mama mówiła mi, że mam chodzić [do szkoły], a później to też miała wywalone... Budziła mnie tam pare razy, ale nie wstawatam, a jak wstawatam to nie poszłam do szkoły (...). Za szkołe trafitam do domu dziecka do sióstr, a wcześniej dostatam kuratora.

Dziewczęta rzadko dostrzegały związek między sytuacją edukacyjną i umieszczeniem $\mathrm{w}$ placówce opiekuńczo-wychowawczej a szeroko rozumianą sytuacją rodzinną. Wielokrotnie skrajnie trudna sytuacja $\mathrm{w}$ domu rodzinnym, przemoc, czy alkoholizm rodziców utrudniała dziewczętom, biorącym udział $\mathrm{w}$ badaniu, funkcjonowanie $\mathrm{w}$ środowisku szkolnym. Badane młode kobiety wskazują na problemy z koncentracją uwagi, co spowodowane było obawami, czy ich najbliższym, którzy pozostali $\mathrm{w}$ domu, nie zagraża niebezpieczeństwo.

[Pola] (...) byłam w szkole i myślałam... co się $w$ domu z mama dzieje? Czy ktoś jej (matki Poli) nie krzywdzi? [Pola wskazała wcześniej, że partner matki stosował wobec niej przemoc o charakterze fizycznym i psychicznym].

Wszystko to, w przypadku badanych dziewcząt, ułatwiało podjęcie decyzji o porzuceniu nauki. Zaś liczne nieobecności, narastające zaległości w wiedzy spowodowane czasami kilkuletnią nieobecnością utrudniały podjęcie decyzji o powrocie do szkoły.

[Pola] Początek tych blauek, im więcej mnie nie było, tym trudniej było wracać do szkoły, bo mniej wiedziałam na jakim etapie sa. Oni byli już wyżej a ja oślica...

\section{Sytuacja szkolna dziewcząt w trakcie ciąży i po urodzeniu dziecka, podczas pobytu w placówce opiekuńczo-wychowawczej}

Wszystkie dziewczęta biorące udział w badaniu zostały umieszczone w placówkach opiekunczo-wychowawczych z powodu trudnej sytuacji rodzinnej. Umieszczenie w placówce związane było z przemijającą, ale jednak, koniecznością odseparowania od rodziny. Ponadto, wiązało się nierozerwalnie ze zmianą szkoły, a w konsekwencji spowodowało utratę i zerwanie dotychczasowych znajomości i potrzebę realizowania obowiązku nauki $\mathrm{w}$ zupełnie nowym otoczeniu społecznym. Było to niewątpliwie trudne dla dziewcząt doświadczających $w$ jednym czasie tak silnych emocji związanych z umieszczeniem w (czasami kolejnej już) placówce, ciążą, urodzeniem dziecka, realizacją nowych, nieznanych dotąd obowiązków, koniecznością zaaklimatyzowania się $\mathrm{w}$ nowej roli. 
[Angelika] (...) Najgorsze było to, że poszłam do nowej szkoty w ciaży i czułam się tak dziwnie. Wchodzę do tej szkoty i czuje się źle (...). Pamiętam, że weszłam do klasy i pani mnie przedstawiała, że nowa uczennica... Na szczęście nie powiedziała, że z placówki, albo coś takiego, bo to już by było w ogóle... zapadłabym się chyba pod ziemię. (...).

Dla wielu badanych dziewcząt zmiana szkoły była kolejnym trudnym wyzwaniem, kolejnym kryzysem, któremu w niesprzyjających okolicznościach musiały stawić czoła. Zmiana otoczenia powodowała ponowną konieczność zmagania się ze wstydem związanym z (przed)wczesną ciążą i funkcjonowaniem w roli wychowanka placówki oraz domysłami "co pomyślą inni?”. Być może właśnie dlatego, jak wskazuje Paulina BunioMroczek, wiele nastoletnich matek rezygnuje $\mathrm{z}$ kontynuowania edukacji krótko po uzyskaniu informacji o tym, że spodziewają się dziecka.

Pewna grupa badanych kobiet sama decydowała się opuścić szkołę, kiedy orientowały się, że są w ciąży. (...) Niektóre uczestniczki wywiadów argumentowały swoje decyzje strachem o nienarodzone dziecko i brakiem bezpieczeństwa na szkolnych korytarzach (...). Respondentki w większości uznawały decyzję o rezygnacji z nauki w obliczu ciąży za naturalną21.

Autorka, w mojej ocenie, słusznie zauważa, iż

biorąc pod uwagę trudności szkolne, których doświadczały jeszcze przed zajściem w ciążę, a czasami od samego początku swojej kariery szkolnej, można przypuszczać, że ciąża stanowiła dla nich swoisty pretekst, żeby wreszcie szkołę opuścić22.

W przypadku wychowanek placówek opiekuńczo-wychowawczych rezygnacja i nierealizowanie obowiązku szkolnego może prowadzić do usunięcia z placówki opiekuńczo-wychowawczej.

\section{Wsparcie grona pedagogicznego i pracowników placówki opiekuńczo-wychowawczej mimo braku uregulowań prawnych dotyczących uczennic w ciąży}

Mimo trudnych początków niemal wszystkie dziewczęta biorące udział w omawianych weryfikacjach empirycznych akcentowały troskę i wsparcie

${ }^{21}$ P. Bunio-Mroczek, Nastoletnie rodzicielstwo $w$ tódzkich enklawach biedy, rozprawa doktorska, Łódź 2015, s. 129, http://docplayer.pl/6935699-Nastoletnie-rodzicielstwo-w-lodzkichenklawach-biedy.html, [dostęp: 4.09.2016].

22 Tamże. 
nauczycieli, pedagogów, które zostało im okazywane w tak dramatycznych dla nich okolicznościach. Jednak ich narracje wskazują również, iż dziewczęta zachodzące w ciążę,

będąc jeszcze w szkole (gimnazjum lub szkole zawodowej ponadgimnazjalnej), napotykają problem $\mathrm{w}$ postaci braku procedur postępowania $\mathrm{z}$ ciężarną uczennicą. Przepis Ustawy o planowaniu rodziny, ochronie płodu ludzkiego i warunkach dopuszczalności przerywania ciąży ${ }^{12}$, której art. 2, par. 3, który mówi, że Szkoła ma obowiązek udzielić uczennicy w ciąży urlopu oraz innej pomocy niezbędnej do ukończenia przez niq edukacji (...) nie jest doprecyzowany przez żaden inny oficjalny dokument. W praktyce, szkoły wypracowują własny sposób postępowania wobec ciężarnych uczennic, którym sugerują staranie się o nauczanie indywidualne, zwykle przyznawane na okres ciąży23.

Paulina Bunio-Mroczek na podstawie wywiadów przeprowadzonych zarówno z nastoletnimi matkami, jak i pedagogami, wskazuje, że "szkoły nie wypracowały formalnych procedur postępowania, mimo powtarzających się ciąż i urodzeń wśród uczennic" 24 . Wspomniana autorka wskazuje, iż w takich sytuacjach najczęściej stosuje się

pół-oficjalne rozwiązania, dostosowane do konkretnych przypadków i okoliczności, takie jak możliwości uczennicy, zakres wsparcia udzielanego jej przez rodzinę, termin porodu w odniesieniu do cyklu roku szkolnego ${ }^{25}$.

Dziewczęta $w$ swoich narracjach mocno akcentują fakt, iż nie były pierwszymi uczennicami w ciąży lub z dzieckiem i dlatego, ich zdaniem, mogły liczyć na pomoc, wyrozumiałość i wsparcie emocjonalne ze strony grona pedagogicznego. Jak uważają, było to konsekwencją wcześniejszych doświadczeń nauczycieli z uczennicami oczekującymi narodzin dziecka. Analiza narracji badanych matek wskazuje, że w szkole takie sytuacje nie należały wcale do rzadkości, co ilustruje, jak duża jest skala zjawiska, szczególnie wśród młodszych nastolatek.

[Pola] W ogóle nauczyciele byli w porządku, wyrozumiali byli, już mieli takie przypadki, tak że dla nich to byto też normalne.

[Julia] $W$ szkole (w trakcie pobytu $\mathrm{w}$ pierwszej placówce) u mnie tam $w$ tym OHP to nauczyciele tam byli normalnie tam... Byli w porzadku, bo tam byly dziewczyny tė̇ przeważnie w ciąży (... ). W tej drugiej szkole też nie było problemów, tam też byli przyzwyczajeni do tego.

\footnotetext{
${ }^{23}$ P. Bunio-Mroczek, W. Warzywoda-Kruszyńska, Wczesne rodzicielstwo jako zagrożenie bieda.

${ }^{24}$ P. Bunio-Mroczek, Nastoletnie rodzicielstwo w tódzkich enklawach biedy, s. 129.

25 Tamże.
} 
Dziewczęta podkreślały często, że mogły liczyć na „wyrozumiałość” nauczycieli.

[Monika] Nauczyciele dobrze, w porządku, właśnie wiedzieli wszyscy, i jak tam właśnie nie miałam jakiegoś zadania (...) na drugi dzień mogłam przynieść (...) coś poprawić, uzupetnić, zrobić... w porzadku byli...

Autorki Raportu „Wczesne rodzicielstwo jako zagrożenie biedą i wykluczeniem społecznym" zauważają, że

po urodzeniu dziecka, kiedy nie ma już podstaw do przyznania indywidualnego nauczania, szkoły obniżają uczennicom z małymi dziećmi wymagania, umożliwiając im uzyskanie świadectwa ukończenia danego etapu edukacji. Tego rodzaju praktyki są bardzo pozytywnie oceniane przez same zainteresowane. Jednakże ich stosowanie prowadzi do obniżenia jakości nauczania w przypadku uczennic w ciąży i z dziećmi, co może stanowić istotną barierę dla kontynuowania przez nie edukacji na wyższym poziomie ${ }^{26}$.

Kilka dziewcząt biorących udział w badaniu wspomniało, że nauczyciele oprócz wsparcia emocjonalnego i informacyjnego zaoferowali im również wsparcie rzeczowe.

[Daria] Pani od matematyki to mi nawet rzeczy dała, bo miała już dwójkę dzieci i wózek też od niej dostałam, bo ja nie wiedziałam, że placówka też daje (...).

Dziewczęta w swoich narracjach, oprócz wsparcia i wyrozumiałości grona pedagogicznego, akcentują również wsparcie, jakie otrzymywały od kolegów i koleżanek z klasy.

\section{Uczennica w ciąży - brak wsparcia nauczyciel i rówieśników}

Mimo że większość dziewcząt biorących udział w badaniu mogła liczyć na wsparcie nauczycieli, i charakterystyczne są dla nich pozytywne doświadczenia szkolne zarówno w czasie ciąży, jak i po urodzeniu dziecka, zdarzały się sytuacje, kiedy grono pedagogiczne zachowywało się nieprofesjonalnie, a dziewczęta nie mogły liczyć na pomoc z ich strony. Jednak, jak podkreślają dziewczęta, takie sytuacje zdarzały się niezwykle rzadko.

[Mirka] Generalnie było dobrze, tylko pedagog kiedyś głupio mi tam jakoś dogadała, właśnie, że z ciąża, że poszłam w siostry ślady, coś takiego...

[Asia] Raz tylko pamiętam, jak ksiądz po religii, coś mi tam dogadat, że taka młoda $z$ dzieckiem, że wstyd $i$ coś tam...

\footnotetext{
${ }_{26}$ P. Bunio-Mroczek, W. Warzywoda-Kruszyńska, Wczesne rodzicielstwo jako zagrożenie bieda.
} 
Nieliczne dziewczęta biorące udział w badaniu akcentowały jawny brak wsparcia ze strony koleżanek i kolegów z klasy, jednak takie sytuacje były niezwykle rzadkie.

[Daria] W klasie niektóre dziewczyny, które się panoszyły po szkole wyzywaty mnie, że nie mam co robić - tylko sobie dzieci robić.

Wyżej opisane zjawisko potwierdzają wpisy na forach internetowych, gdzie młodzież ze szczegółami opisuje nieprofesjonalne i niezgodne z prawem zachowania nauczycieli oraz dyrekcji wobec uczennic w ciąży.

Uczę się $w$ jednym $z$ lepszych liceów w regionie, (...) moja koleżanka jest w cią$\dot{z}$. Kończymy właśnie druga klasę, a ona zdecydowata, że chce urodzić $i$ wrócić do szkoły i zdać maturę. (...) I co? Tu szkoła stawia trudności, w szczególności dyrekcja i wychowawca wmawiaja dziewczynie, że sobie nie poradzi. (...) chce się pozbyć problemu. (...) buntuje nauczycieli, pedagoga, pielegniarki i wychowawczynie przeciwko niej (...). Zero jakiegokolwiek wsparcia i pomocy27.

Także liczni autorzy zauważają, że mimo postępu cywilizacyjnego takie sytuacje, niestety, nie należą do rzadkości ${ }^{28}$.

\section{Matka i uczennica - trudność w łączeniu ról w trakcie pobytu w placówce}

Badane dziewczęta w swoich narracjach akcentują znaczenie edukacji i nauki w placówce opiekuńczo-wychowawczej.

[Hania] W placówce nie ma zmiłuj. Trzeba chodzić do szkoty. Inaczej MOW [Młodzieżowy Ośrodek Wychowawczy] cię czeka albo dzieciaka zabierają.

Niemal każda zauważa, że dzięki pobytowi w placówce możliwa stała się realizacja obowiązku szkolnego, a niektórym dziewczętom, biorącym udział $\mathrm{w}$ prezentowanym fragmentarycznie badaniu, udało się skończyć szkołę na etapie rozpoczętym $\mathrm{w}$ trakcie pobytu $\mathrm{w}$ instytucji.

[Pola] Jak się zaczęta szkoła... No to się wtedy wszystko zaczęło, całe piekło (śmiech). Było ciężko, tym bardziej że malutka się budziła bardzo często w nocy i to tak do niecałego roczku. A ja na dodatek wcześniej musiałam wstawać, żeby się naszykować... (...) Zasypiałam na lekcji, czasami zdarzało się, że odpływałam, albo nie kontaktowałam (...).

${ }^{27}$ Autor: Licealistka http://szkola.wp.pl/kat,108836,title,Ciaza- szkole,wid,12353076, wiadomosc.html?ticaid=110ff2 [dostęp 22.07.2013].

${ }_{28}$ Por. M. Bidzan, Nastoletnie matki. Psychiczne aspekty ciąży, porodu i połogu, Kraków 2007; A. Skowrońska-Zbierzchowska, Doświadczenia małoletnich rodziców. 
Wszystkie dziewczęta objęte badaniami podkreślały, jak bardzo trudno było im godzić rolę uczennicy z rolą matki, nawet uzyskując wsparcie ze strony pracowników placówki opiekuńczo-wychowawczej.

\section{Opuszczenie placówki opiekuńczo-wychowawczej - edukacyjne konsekwencje (przed)wczesnego macierzyństwa}

Niemożność kontynuowania edukacji stanowiła istotny obszar dotkliwie odczuwanych konsekwencji wynikających z (przed)wczesnego macierzyństwa po opuszczeniu placówki opiekuńczo-wychowawczej. Większość badanych dziewcząt po opuszczeniu placówki porzuciło szkoły i przerwało naukę.

[Julia] Ja bym chciała wrócić do szkoty, ale nie mam jak - oni sa mali. Ja bym chciata, ale najgorsze jest to, że nie mam jak.

Prezentowane weryfikacje empiryczne potwierdziły, że wczesne rodzicielstwo redukuje czas trwania nauki. Wychowankom placówek opiekunczo-wychowawczych, pochodzącym z rodzin o niskim wykształceniu i kwalifikacjach zawodowych, dodatkowo utrudniając lub uniemożliwiając osiągnięcie wykształcenia średniego, a nawet gimnazjalnego. Brak wykształcenia i kwalifikacji zawodowych prowadził do podejmowania (jeśli w ogóle się to udawało) niskopłatnych, nie wymagających kwalifikacji prac lub pozyskiwania środków do życia w sposób niezgodny z prawem.

[Renata] (...) Bo moim zadaniem jest, żeby wzią́ bezdomnego pijaka, on go ubierze jakoś, ja z nim idę do banku jako jego siostrzenica, czy córka, czy Bóg wie co i bierzemy kredyt na czterdzieści tysięcy, no i najważniejsze żeby facet się nie odzywat.

Dla małoletnich matek i przyszłości ich dzieci niezwykle istotnym elementem, który może pomóc wyjść z sytuacji kryzysowej jest edukacja. Ukończenie szkoły, zdobycie wykształcenia i kwalifikacji zawodowych jest w takich okolicznościach nie do przecenienia ${ }^{29}$. Niestety, jak wskazują wyniki omawianych weryfikacji empirycznych większość dziewcząt po opuszczeniu placówki opiekuńczo-wychowawczej nie kontynuowała nauki. Przyczyn tego stanu rzeczy nie należy upatrywać jedynie w oddziaływaniach środowiska szkolnego. Omawiane weryfikacje empiryczne nie potwierdziły wniosków Alicji Skowrońskiej-Zbierzchowskiej i nie wykazały niechęci „do

29 Por. G. Mikołajczyk-Lerman, Małoletnie rodzicielstwo jako problem psychospołeczny, Polityka Społeczna, 2007, 8, https://www.ipiss.com.pl/wp-content/uploads/downloads/2012/ 10/ps_8_2007_g_mikolajczyk-lerman.pdf [dostęp: 12.04.2016]. 
udzielania pomocy uczennicom, które obok nowo podjętych obowiązków rodzicielskich mają wieloletnie zaległości w nauce, niską motywację do niej i niezaradnych rodziców" 30 . Należy zauważyć, że niemal wszystkie dziewczęta biorące udział $\mathrm{w}$ badaniu charakteryzowały się wyżej wskazanymi cechami, a mimo to, jak wskazywały, czuły wsparcie ze strony nauczycieli. W związku z tym należy zauważyć, że sama inicjatywa i aktywność środowiska szkolnego nie wystarcza, by zapobiec przerywaniu edukacji, a tym samym powielaniu niskiego statusu społecznego, który może być efektem braku wykształcenia charakterystycznego dla rodzin pochodzenia tych uczennic, a w konsekwencji prowadzić do ich społecznego wykluczania. Dziewczęta, mimo wsparcia grona pedagogicznego, po opuszczeniu placówki przerywały naukę. Kontynuowanie jej po opuszczeniu placówki, jak wynika z narracji badanych dziewcząt, uzależnione było od wsparcia udzielonego młodym matkom przez ich najbliższych. Wsparcie, jak wskazały badane kobiety, było niewielkie lub żadne, więc tylko nieliczne kontynuowały lub ukończyły naukę $\mathrm{w}$ szkole średniej. W związku z powyższym, warto wskazać na istotną rolę instytucji pomocowych $\mathrm{w}$ zakresie pracy $\mathrm{z}$ rodziną pochodzenia $\mathrm{w}$ trakcie pobytu dziewcząt $\mathrm{w}$ placówkach.

\section{Wsparcie w łączeniu roli uczennicy z rolą matki - kontynuacja nauki}

Dziewczęta, którym w wypełnianiu obowiązków macierzyńskich pomagali rodzice czy inne bliskie osoby częściej podejmowały dalszą naukę bezpośrednio po opuszczeniu placówki opiekuńczo-wychowawczej. W przypadku prezentowanych badań tylko trzy $\mathrm{z}$ badanych dziewcząt łączy obowiązki matki z nauką szkolną.

[Mirka] Ja mam dobrze, bo akurat to mam bezpłatne liceum (...). No i jakoś tak powiem, że udaje się to pogodzić, ale łatwo nie jest. Siostra mi pomaga też. Facet też, nie mogę narzekać, bo też mi pomaga. (...). Czasami koleżanka (...).

Należy zauważyć, że „jeśli kobiety decydują się kontynuować naukę, wybierają niepubliczne wieczorowe szkoły, świadczące usługi edukacyjne o bardzo niskiej jakości, z czego same respondentki zdają sobie sprawę"31. Było to również charakterystyczne dla uczących się matek biorących udział $\mathrm{w}$ omawianych weryfikacjach empirycznych.

\footnotetext{
30 A. Skowrońska-Zbierzchowska, Doświadczenia małoletnich rodziców, s. 205.

${ }^{31}$ P. Bunio-Mroczek, W. Warzywoda-Kruszyńska, Wczesne rodzicielstwo jako zagrożenie bieda.
} 
[Asia] Ja po wyjściu [z placówki] skończyłam wieczorówkę, to znaczy takie prywatne liceum, jakoś się udało, ale łatwo nie byto [śmiech]. Ale tam lightowo byto, no ale wiadomo, jak już jest dziecko to nawet light nie jest taki lightowy. [śmiech]. (...) więcej mnie nie byto niż bytam (...).

Paulina Bunio-Mroczek, powołując się na wypowiedzi swoich rozmówczyń (nastoletnich matek z łódzkich enklaw biedy), wskazuje, iż

zajęcia w szkołach tego typu nie odbywały się lub program i wymiar realizowanych godzin nauczania zostawał istotnie ograniczony. $Z$ wywiadu z ekspertem wynika, że szkoły te nie posiadają stałej kadry pedagogów, a nauczyciele zatrudniani są na podstawie umowy zlecenia (...) i najprawdopodobniej celowo „przyjmują” fikcyjnych uczniów, którzy nie uczęszczają na zajęcia ${ }^{32}$.

\title{
Brak wsparcia - przerwanie edukacji
}

\author{
Rola ucznia, jak wskazuje Urszula Kempińska,
}

pozostaje w sprzeczności z formułą człowieka usamodzielnionego, zakładającego rodzinę. Do takiej niezwykłej sytuacji niełatwo się przystosować (...) zwłaszcza gdy pociąga to za sobą dodatkowe, dotkliwie odczuwalne $w$ budżecie rodzinnym świadczenia materialne oraz wysiłek fizyczny, związany z utrzymaniem pozostałych domowników, w tym małego dziecka $(. . .)^{33}$.

W sytuacji, kiedy dziewczęta nie mogły liczyć na wsparcie najbliższych, najczęściej przerywały naukę. Nie miały bowiem z kim zostawić dziecka na czas zajęć lekcyjnych, a po powrocie ze szkół realizacja obowiązków uczniowskich była utrudniona $\mathrm{z}$ uwagi na niezwykle absorbujące zadania związane z opieką nad małym dzieckiem.

[Julia] Ja bym chciała wrócić do szkoty, ale nie mam jak - oni sa mali. (...). Mama jak nie pracowała to troche pomagała, jak się Wanessa urodziła, była mała, to chyba ze dwa miesiace była tutaj u nas... i tam pomagała. A później właśnie dostała pracę (...).

Grażyna Mikołajczyk-Lerman wskazuje, że

im większe aspiracje $\mathrm{w}$ zakresie edukacji i osiągania pozycji społecznej posiadają młodzi ludzie, tym trudniejsze może być pogodzenie się z chwilową bądź stałą utratą tych możliwości rozwojowych w przypadku zbyt wczesnego rodzicielstwa ${ }^{34}$.

\footnotetext{
32 P. Bunio-Mroczek, Nastoletnie rodzicielstwo w tódzkich enklawach biedy, s. 131.

33 U. Kempińska, Małżeństwa młodocianych, s. 90-91.

${ }^{34}$ G. Mikołajczyk-Lerman, Małoletnie rodzicielstwo, s. 56.
} 
Co charakterystyczne, w przypadku badanych dziewcząt, mimo iż, jak same deklarowały, nigdy nie motywowano je do nauki, nie charakteryzowały się wysokimi aspiracjami edukacyjnymi, a jednak dotkliwie odczuwają niemożność kontynuowania edukacji.

[Pola] Jestem na drugim etapie, znaczy... to znaczy $w$ drugiej klasie. Pierwsza klasę [gimnazjum] skończyłam po wyjściu z placówki, zaczęłam druga i w połowie drugiej wtaśnie zaniedbałam troszkę, nie miałam możliwości dziecka zostawić... trudna to była decyzja.

Warto podkreślić, iż z realizacji własnych aspiracji i planów, w tym edukacyjnych, zawsze musiały rezygnować kobiety. Wśród badanych dziewcząt niemal wszystkie (poza dwoma) zmuszone zostały do przerwania nauki. $\mathrm{W}$ wielu przypadkach nie mogły one liczyć ani na pomoc partnera, ani rodziny.

[Ola] Każdy tam się pyta dlaczego zrezygnowataś? No, ale wtedy to jednak miatam już wszystko na glowie, bo to jednak zrobić rzeczy w domu i przy matym no to też była duża odpowiedzialność. (...) a jak bym mieszkała z mama albo tam u mamy to przypuszczam, że chodziłabym do tej szkoty, bo mama mi tam by dużo pomogła. (...) Ja tam dużej pomocy nie miałam jak urodzitam, (...). No ale ogólnie no to trochę wyrzeczeń było i do tej szkoty nie dawatam rady chodzić (...).

Niepokoi fakt, że zdobycie wykształcenia, a tym samym zwiększenie swoich szans na lepszą pracę oraz związana z tym nadzieja na spokojniejszą przyszłość dla siebie i dziecka okazały się niemożliwe do osiągnięcia, nawet przez te $z$ badanych dziewcząt, które doświadczyły akceptacji, a nawet szeroko rozumianego wsparcia w środowisku szkolnym. Tylko te, które otrzymały wsparcie $w$ opiece nad dzieckiem od najbliższych, co nie jest łatwe w przypadku wychowanków placówek opiekuńczo-wychowawczych, mogły kontynuować naukę szkolną. Jednakże, nie można powiedzieć, że któraś z dziewcząt odniosła sukces edukacyjny (ukończyła studia wyższe, osiągała bardzo dobre wyniki $w$ nauce). $\mathrm{W}$ przypadku weryfikacji prowadzonych przez Alicję Skowrońską-Zbierzchowską ${ }^{35}$, sukces edukacyjny osiągali ci nastoletni rodzice, którzy wcześniej otrzymywali dobre i bardzo dobre wyniki w nauce, co nie było charakterystyczne dla dziewcząt biorących udział w prezentowanych weryfikacjach empirycznych.

Badania potwierdziły tezy stawiane przez znawców problematyki (przed)wczesnego rodzicielstwa w dziedzinie edukacji. Prawdziwy okazał się fakt, iż wczesne rodzicielstwo przyczynia się do opóźnienia lub skrócenia kariery edukacyjnej. Analiza narracji badanych osób wskazuje, że małoletnim matkom, wychowankom placówek opiekuńczo-wychowawczych,

35 Por. A. Skowrońska-Zbierzchowska, Doświadczenia małoletnich rodziców, Gdańsk 2010. 
wywodzącym się z rodzin o niskim statusie społeczno-ekonomicznym, wczesne rodzicielstwo dodatkowo utrudnia osiągniecie średniego, a nawet gimnazjalnego wykształcenia, tym samym umacniając ich „wyjściowe” gorsze położenie społeczno-ekonomiczne ${ }^{36}$. Z pewnym prawdopodobieństwem, jak to czyni A. Skowrońska-Zbierzchowska odwołując się do teorii P. Bourdieu, można wnioskować, iż doświadczenia szkolne małoletnich matek, wychowanek placówek opiekuńczo-wychowawczych, tak dla dalszego funkcjonowania ich samych oraz ich dzieci, $\mathrm{w}$ dużym stopniu zdeterminowane zostały przez posiadany kapitał kulturowy i społeczno-ekonomiczny ${ }^{37}$.

\section{Edukacja - priorytet? - brak systemowej pomocy}

W Polsce, jak wcześniej wspominałam, istnieje jeden zapis dotyczący edukacji uczennic w ciąży lub małoletnich matek. Jest on jednak mało precyzyjny, co sprawia, że szkoły same muszą sobie w takich sytuacjach radzić. W związku z tym wdrażają doraźnie swoje procedury. Najczęściej jest to zasugerowanie uczennicy w ciąży trybu nauczania indywidualnego, co nierozerwalnie związane jest $\mathrm{z}$ odseparowaniem od rówieśników.

W literaturze anglojęzycznej autorzy zwracają uwagę, iż mimo rozwiniętej sieci systemowej pomocy w szkołach dochodzi do głosu „dyskurs zaraźliwości”. Ciąża traktowana jest jak choroba, którą mogą zarazić się inne dziewczęta. Dlatego, dziewczęta w ciąży należy usuwać ze szkół, należy je izolować. W Stanach Zjednoczonych czy w Wielkiej Brytanii mówi się coraz głośniej o zjawisku gettoizacji małoletnich uczennic w ciąży lub małoletnich matek objętych obowiązkiem nauki ${ }^{38}$. W Polsce również ten problem występuje ${ }^{39}$. Wyniki moich weryfikacji wskazują, że dziewczętom zaoferowano pomoc, nikt nie zmuszał ich do zmiany szkoły. Natomiast, szczegółowa analiza narracji badanych matek wskazuje, że pomoc polegała głównie na obniżaniu standardów, przymykaniu oczu na liczne nieobecności. Takie strategie pomocy Wielisława Warzywoda-Kruszyńska czy Paulina Bunio-Mroczek nazywają "niedźwiedzią przysługą"40. Praktyka taka powoduje, że o ile dziewczęta kończą edukację na poziomie, w którym zaszły w ciążę, trudniej

36 Tamże.

37 A. Skowrońska-Zbierzchowska, Doświadczenia małoletnich rodziców, s. 185.

${ }^{38}$ P. Bunio-Mroczek, Nastoletnie rodzicielstwo jako problem społeczny, s. 62.

39 Por. A. Skowrońska-Zbierzchowska, Doświadczenia matoletnich rodziców; M. Bidzan, Nastoletnie rodzicielstwo.

${ }^{40}$ Por. P. Bunio-Mroczek, W. Warzywoda-Kruszyńska, Wczesne rodzicielstwo jako zagrożenie bieda. 
im jednak kontynuować edukację na poziomie wyższym, co znalazło wyraz w omawianych weryfikacjach empirycznych.

Narracje badanych wskazują, że uwikłanie we wczesne rodzicielstwo i niesamodzielność życiowa stają się źródłem wielu trudności. Młode matki opuszczające placówki opiekuńczo-wychowawcze napotykają na swej samodzielnej drodze wiele problemów. Do najczęściej występujących, które stają się udziałem grup defaworyzowanych, wynikających zarówno z zaistnienia (przed)wczesnej ciąży, jak i związanych z opuszczeniem placówki opiekuńczo-wychowawczej, można zaliczyć: znacznie bardziej ograniczone możliwości rozwoju osobistego i zawodowego uniemożliwiające skuteczne znalezienie się na współczesnym rynku pracy. Jak wskazano wcześniej, duża część wychowanek biorących udział w prezentowanych badaniach przerywa edukację, kończąc ją bardzo wcześnie (najczęściej na poziomie szkoły gimnazjalnej), co determinuje trudną sytuacją materialno-bytową na skutek długotrwałego bezrobocia. „A to w konsekwencji przyczynia się do wykształcania postaw bierności i nadmiernej zależności od instytucji pomocowych (pomocy społecznej)" 41 .

Wobec tych niepokojących danych dziwić powinien fakt, iż małoletnie uczennice w ciąży lub małoletnie uczennice $\mathrm{z}$ dziećmi nie są objęte systemową pomocą. Ich sytuacja nie jest przedmiotem debaty publicznej, a jeśli się pojawia, to zazwyczaj w następstwie sensacyjnych doniesień, które dotyczą nastoletnich matek. Dzieje się tak pomimo że znawcy przedmiotu alarmują, iż wczesne macierzyństwo redukuje czas trwania edukacji, co powoduje, że dziewczynie, w sposób szczególny byłej wychowance POW, bardzo trudno odnaleźć się na rynku pracy. Mówi się o spirali niepowodzeń - nieletnia matka, brak edukacji, brak wykształcenia, brak kwalifikacji, w związ$\mathrm{ku} \mathrm{z}$ tym problem ze znalezieniem pracy sprzyjający uzależnieniu od pomocy społecznej. W takiej sytuacji systemowa pomoc $\mathrm{w}$ zakresie realizacji obowiązku szkolnego powinna być kwestią priorytetową, tym bardziej że edukacja i wzrost aspiracji edukacyjnych może być czynnikiem chroniącym przed kolejną ciążą42. Ponadto, dla wielu dziewcząt potwierdzenie informacji o ciąży stanowi moment zwrotny (jak to wynika z ich deklaracji) w biografii. To czas wzmożonej refleksji nad własnym życiem oraz przyszłością swoją i nienarodzonego dziecka. To czas, który warto wykorzystać, by

${ }^{41} \mathrm{M}$. Krawiec, Wejście w dorosłe życie - pierwszym poważnym kryzysem, Przedsiębiorczość i Zarządzanie, 2009, X, 11, s. 57, http://docplayer.pl/3519461-Czlowiek-w-kryzysiewspolczesne-problemy-zyciowe-i-zawodowe-przedsiebiorczosc-zarzadzanie-tom-x-zeszyt-11lodz-2009.html, [dostęp: 11.01.2016].

42 Por. H. Bee, Psychologia rozwoju człowieka, Poznań 1998; J.J McWhirter i in., Zagrożona młodzież, Warszawa 2005. 
dziewczęta deklaracje zamieniły w czyny, co w mojej ocenie możliwe jest tylko dzięki współpracy wielu instytucji i systemowemu wsparciu adresowanemu do młodych matek oraz ich rodzin pochodzenia.

\section{BIBLIOGRAFIA}

Bauman T., Zasady badań pedagogicznych. Strategie ilościowe i jakościowe, Wydawnictwo Akademickie Żak, Warszawa 2001.

Bee H., Psychologia rozwoju człowieka, Wydawnictwo Zysk i S-ka, Poznań 1998.

Bidzan M., Nastoletnie matki. Psychiczne aspekty ciąży, porodu i połogu, Oficyna Wydawnicza Impuls, Kraków 2007.

Bidzan M., Nastoletnie rodzicielstwo. Perspektywa psychologiczna, Wydawnictwo Harmonia Universalis, Gdańsk 2013.

Brzezińska A., Społeczna psychologia rozwoju, tom 3, Wydawnictwo Naukowe Scholar, Warszawa 2000.

Brzezińska A., Wydarzenia punktualne i niepunktualne w okresie dzieciństwa $i$ dorastania, Remedium, 2003, 12(130).

Bunio-Mroczek P., Nastoletnie rodzicielstwo jako problem społeczny. Rezultaty badań łódzkich na tle Wielkiej Brytanii i USA, 2010, http://cejsh.icm.edu.pl/cejsh/element/ bwmeta1.element.hdl_11089_254, [dostęp: 11.05.2016].

Bunio-Mroczek P, Nastoletnie rodzicielstwo w łódzkich enklawach biedy, rozprawa doktorska, Łódź 2015, http://docplayer.pl/6935699-Nastoletnie-rodzicielstwo-w-lodzkichenklawach-biedy.html, [dostęp: 4.09.2016].

Bunio-Mroczek P., Warzywoda-Kruszyńska W., Wczesne rodzicielstwo jako zagrożenie bieda $i$ wykluczeniem społecznym, 2010, http://www.wzlot.uni.lodz.pl/pub/dokumenty/ 123234.pdf, [dostęp: 7.05.2016].

Frankowicz-Gasiul B., Michalik A., Czerwińska A., Zydorek M., Olszewska J., Olszewski J., Ciąża młodocianych - problem medyczny i społeczny, Studia Medyczne, 2008, http:/ / docplayer.pl/6714134-Ciaza-mlodocianych-problem-medyczny-i-spoleczny.html [dostęp: 2.02.2014].

Izdebski Z., Niemiec T., Wąż K., (Zbyt)młodzi rodzice, Wydawnictwo Trio, Warszawa 2011.

Kempińska U., Matżeństwa młodocianych. Ciąza, ślub i co dalej...? Wydawnictwo Edukacyjne Akapit, Torun 2012.

Krawiec M., Wejście w dorosłe życie - pierwszym poważnym kryzysem, Przedsiębiorczość i Zarządzanie, 2009, X, 11, http://docplayer.pl/3519461-Czlowiek-w-kryzysiewspolczesne-problemy-zyciowe-i-zawodowe-przedsiebiorczosc-zarzadzanie-tom-xzeszyt-11-lodz-2009.html [dostęp: 11.01.2016].

Kubinowski D., Jakościowe badania pedagogiczne. Filozofia, metodyka, ewaluacja, Wydawnictwo Naukowe Uniwersytetu Marii Curie- Skłodowskiej, Lublin 2010.

Kubinowski D., Nowak M., Metodologia pedagogiki zorientowanej humanistycznie, Oficyna Wydawnicza Impuls, Kraków 2006.

Maciarz A., Macierzyństwo w kontekście zmian społecznych, Wydawnictwo Akademickie Żak, Warszawa 2004.

McWhirter J.J., McWhirter B.T., McWhirter A.M., McWhirter E.H., Zagrożona młodzież, Wydawnictwo Edukacyjne PARPA, Warszawa 2005. 
Mikołajczyk-Lerman G., Małoletnie rodzicielstwo jako problem psychospołeczny, Polityka Społeczna, 2007, 8, https://www.ipiss.com.pl/wp-content/uploads/downloads/ 2012/10/ps_8_2007_g_mikolajczyk-lerman.pdf [dostęp: 12.04.2016].

Pasternak A., Schier K., Życie bez dzieciństwa - parentyfikacja u kobiet $z$ syndromem DDA, Psychiatria Polska, 2014, 48(3).

Pilch T., Bauman T., Zasady badań pedagogicznych. Strategie ilościowe i jakościowe, Wydawnictwo Akademickie Żak, Warszawa 2001.

Rocznik Demograficzny 2013, http://stat.gov.pl/obszary-tematyczne/roczniki-statystycz ne/roczniki-statystyczne/rocznik-demograficzny-2014,3,8.html, [dostęp: 11.01.2015].

Skowrońska-Pućka A., (Przed)wczesne macierzyństwo - perspektywa biograficzna. Diagnoza, pomoc i wsparcie, 2015, niepublikowana rozprawa doktorska.

Skowrońska-Zbierzchowska A., Doświadczenia małoletnich rodziców, Wydawnictwo Uniwersytetu Gdańskiego, Gdańsk 2010.

Szukalski P., Nastoletnie macierzyństwo we wspótczesnej Polsce, Polityka Społeczna, 2011, 1.

Włodarek J., Ziółkowski M., Metoda biograficzna w socjologii, Wydawnictwo Naukowe PWN, Warszawa - Poznań 1990. 
